PACS: 40

\title{
EFFECT OF THE OSCILLATING ELECTRIC FIELD DUE TO THE OSCILLATING ELECTRIC DIPOLE ON RAMAN LINES
}

\author{
Khanna M. Kapil ${ }^{1 *}$, (D) Murei K. Gilbert ${ }^{2}$ \\ ${ }^{I}$ Department of Physics, University of Eldoret \\ P.O Box 1125-30100, Eldoret, Kenya \\ ${ }^{2}$ Department of Physics, Laikipia University \\ P.O. Box 1100-20300, Nyahururu, Kenya \\ E-mail:1*khannak700@gmail.com,2gmurei@laikipia.ac.ke \\ Received September 16, 2019; revised November 22, 2019; accepted November 22, 2019
}

Raman Effect is the measurement of the intensity and wavelength of the inelastically scattered radiation that falls on a molecule. The electric field of the incident radiation polarizes the molecule on which it falls and this leads to the creation of an oscillating dipole. The incident polarized laser light is inelastically scattered by the molecular sample. The scattered light contains modified wavelengths called the Stokes and anti-Stokes lines or wavelengths. The oscillating electric dipole, created by the incident radiation, creates an oscillating electric field around it. Since the oscillating electric field of the incident radiation creates an oscillating electric dipole that create an oscillating electric field around it, it was surmised that this oscillating electric field can affect the frequency of vibration or oscillation of the oscillating electric dipole that produces it. This novel effect will change the frequency (frequencies) of the scattered radiation resulting in Stokes and anti-Stokes lines with modified frequencies. This theoretical research and its importance can be understood like this. For instance, if there are two cells or molecules, side by side, in which one is a healthy cell and the other is cancerous, or two different types of molecules are sitting side by side, this types of scattering should be able to distinguish one from the other since the Stokes and anti-Stokes lines from the two molecules will not be identical. Thus, the incident radiation of angular frequency $\boldsymbol{\omega}_{1}$ polarizes the charges of the molecule on which it falls and this leads to the creation of an oscillating dipole of frequency $\boldsymbol{\omega}_{2}$. The oscillating dipole creates an oscillating electric field that can create additional frequency of the oscillating dipole that created it, and let this be $\boldsymbol{\omega}_{\mathrm{D}}$. Then the Raman lines can have frequencies $\left(\boldsymbol{\omega}_{1}+\boldsymbol{\omega}_{2}+\boldsymbol{\omega}_{\mathrm{D}}\right),\left(\boldsymbol{\omega}_{1}+\boldsymbol{\omega}_{2}-\boldsymbol{\omega}_{\mathrm{D}}\right),\left(\boldsymbol{\omega}_{1}-\boldsymbol{\omega}_{2}+\boldsymbol{\omega}_{\mathrm{D}}\right)$, and $\left(\boldsymbol{\omega}_{1}-\boldsymbol{\omega}_{2}-\boldsymbol{\omega}_{\mathrm{D}}\right)$. Depending on the relative magnitudes of $\boldsymbol{\omega}_{2}$ and $\boldsymbol{\omega}_{\mathrm{D}}$, Raman lines will be designated as Stokes and Anti-Stokes lines. Due to the law of conservation of energy, $\boldsymbol{\omega}_{\mathrm{D}}$ will be less than $\boldsymbol{\omega}_{2}$ since an oscillating dipole cannot create field of frequency more than its own frequency. Hence the frequencies $\left(\boldsymbol{\omega}_{1}-\boldsymbol{\omega}_{2}+\boldsymbol{\omega}_{\mathrm{D}}\right)$ and $\left(\boldsymbol{\omega}_{1}-\boldsymbol{\omega}_{2}-\boldsymbol{\omega}_{\mathrm{D}}\right)$ correspond to Stokes lines, and frequencies. $\left(\boldsymbol{\omega}_{1}+\boldsymbol{\omega}_{2}+\boldsymbol{\omega}_{\mathrm{D}}\right)$ and $\left(\boldsymbol{\omega}_{1}+\boldsymbol{\omega}_{2}-\boldsymbol{\omega}_{\mathrm{D}}\right)$ will correspond to Anti-Stokes lines. Calculations for Stokes and Anti-stokes lines have been done for some molecules, namely Ammonia compound $\left(\mathrm{NH}_{3}\right)$, Nitrousoxide compound $\left(\mathrm{N}_{2} \mathrm{O}\right)$, Water $\left(\mathrm{H}_{2} \mathrm{O}\right)$, Sulphur dioxide compound $\left(\mathrm{SO}_{2}\right)$, Ozone compound $\left(\mathrm{O}_{3}\right)$. Calculations have also been done for compounds containing carbon, such as Dichloromethane compound $\left(\mathrm{CH}_{4} \mathrm{Cl}_{2}\right)$, $\mathrm{Formic}$ acid compound $\left(\mathrm{CH}_{2} \mathrm{O}_{2}\right)$, Methanol compound $\left(\mathrm{CH}_{4} \mathrm{O}\right)$, Benzene compound $\left(\mathrm{C}_{6} \mathrm{H}_{6}\right)$, Propane compound $\left(\mathrm{C}_{3} \mathrm{H}_{8}\right)$, and Carbonyl chloride compound $\left(\mathrm{Cl}_{2} \mathrm{CO}\right)$. The theory developed predicts new phenomena of getting Stokes and anti-Stokes lines with modified wavelengths which have not been observed experimentally as of to-day.

KEYWORDS: electric dipole, Raman lines, Stokes lines, anti-Stokes lines, oscillating electric dipole

Inelastic scattering of light by a molecular sample was first predicted theoretically by Adolf Smekel [1] in 1923. The phenomenon was experimentally discovered in 1928 by an Indian Scientist C.V Raman [2,3]. He discovered the phenomena using filtered sunlight as a monochromatic source of photons, a colored filter as a monochromator, and a human eye as a detector. Originally Raman and Krishna observed the scattering of spectrally filtered sunlight from a liquid and observed that the scattered light contained very weak signals of light that had slightly different frequencies compared to the frequency of the incoming light. Some of the incident photons are elastically scattered (Rayleigh scattering), and it is found that hardly 1 in $10^{7}$ incident photons are elastically scattered. The number of inelastically scattered photons is much less. Quantum-mechanically, this process of scattering is interpreted as the shifted quantum states of the molecule. However, the intensity of the Raman signal is very low since hardly in 1 in $10^{8}$ incident photons are inelastically scattered. The shifted quantum states lead to shifted frequencies in the scattering process, and these appear symmetrically around the frequency of the exciting radiation. This leads to the conclusion that the molecule may be either excited or de-excited during the scattering process. If the molecule is excited before the scattering event, it leads to Stokes scattering i.e., if $\boldsymbol{\omega}_{\text {laser }}$ is the frequency of the incident light and $\boldsymbol{\omega}_{\mathrm{s}}$ is the frequency of the scattered light, then the Raman shift in frequency (Stokes lines) is $\Delta \boldsymbol{\omega}=\boldsymbol{\omega}_{\text {laser }}-\boldsymbol{\omega}_{\mathrm{s}}$ which is positive. However, when the molecule is de-excited, the Raman shift in the frequency will be such that $\boldsymbol{\omega}_{\mathrm{s}}>\boldsymbol{\omega}_{\text {laser, }}$, and these Raman lines are called anti-Stokes lines. Hence, the frequencies of the Raman lines depend on the states of excitation of the molecule on which the incident radiation falls.

Now it is well known that when light falls on a molecule, the molecule is polarized by the electric field of the incident radiation (also called the incident field). Both linear and nonlinear optical effects can be understood as resulting from the interaction of the electric field component of the incident electromagnetic radiation with the charged particles of the molecule or material. In general, an applied electric field moves positive charges in the direction of the electric field, and negative charges in the opposite direction. The electric field associated with the visible and near-infrared range of the electromagnetic spectrum oscillates at frequencies in the range of the $103 \mathrm{THz}$. These driving frequencies are quite large such that light particles, like electrons in the molecules or material follow the rapid oscillations of the driving field. This 
is not the case for nuclei that are heavy particles. As a result of the driving fields, the bound electrons are slightly displaced from their equilibrium position. This process creates induced oscillating dipole that creates oscillating electric field. This oscillating electric field can affect the state of polarization of the molecule that created it, and also the quantum states of the molecule. It is this phenomenon that motivated us to study its effect on the frequencies of the resulting Stokes and anti-Stokes lines. It needs to be emphasized that the spectroscopic technique based on Raman scattering has been widely used in chemical analysis, study of biomolecules, crystals and powders, food industry, medical and environmental applications. The greatest advantage of this technique is that it requires very little or no sample preparation. The theory developed in this manuscript and the experimental techniques that may be developed in future could be very useful in medical science since the technique could be used to locate the disease in hidden parts of the body without destroying or affecting any internal structure or organs of the body [4].

We will now describe the basic ideas that will lead to the development of the theory suggested in this paper. It is well known that a dipole creates an electric field, say $\mathbf{E}_{\mathbf{d}}$, that polarizes the solid [5-7]. If all the molecules of the system are at one place, they all get polarized (i.e. each molecule acquires an induced dipole moment) and each causes an electric field at some point $\mathbf{r}_{\mathbf{o}}$ where the local field is calculated. An oscillating molecule under the action of an electric field $\left(\mathbf{E}_{\mathbf{i}}\right)$ from the incident radiation will develop an oscillating dipole resulting in the creation of an oscillating electric field $\left(\mathbf{E}_{\mathbf{L}}\right)$. The magnitude of the molecular response is proportional to the sum of all the fields $\left(\mathbf{E}_{\mathbf{i}}+\mathbf{E}_{\mathbf{L}}\right)$ acting at the same or some point $\mathbf{r}_{\mathbf{o}}$, and the sum of these fields is called primary field. More explicitly we write the fields at the position $\mathbf{r}_{\mathbf{o}}$ at the time $\mathbf{t}$ as, $\mathbf{E}_{\mathbf{i}}\left(\mathbf{r}_{\mathbf{0}}, \mathbf{t}\right)$ and $\mathbf{E}_{\mathbf{L}}\left(\mathbf{r}_{\mathbf{0}}, \mathbf{t}\right)$, and the primary field say,

$$
\mathrm{E}_{\mathrm{p}}\left(\mathrm{r}_{0}, \mathrm{t}\right)=\mathrm{E}_{\mathrm{i}}\left(\mathrm{r}_{0}, \mathrm{t}\right)+\mathrm{E}_{\mathrm{L}}\left(\mathrm{r}_{0}, \mathrm{t}\right) .
$$

Now if $\boldsymbol{\omega}_{1}$ is the frequency of the incident radiation, $\boldsymbol{\omega}_{2}$ is the frequency of vibration of the induced of the molecule receiving the incident radiation (the frequency of the induced dipole is not to be confused with the natural frequency of vibration of the molecule), and $\boldsymbol{\omega}_{\mathrm{D}}$ is the frequency of the oscillating electric field created by the oscillating molecular dipole, then the frequencies of the Raman scattering or Raman lines or Raman scattered radiation can be,

$$
\begin{aligned}
& \boldsymbol{\omega}_{1}+\boldsymbol{\omega}_{2}+\boldsymbol{\omega}_{\mathrm{D}}, \\
& \boldsymbol{\omega}_{1}+\boldsymbol{\omega}_{2}-\boldsymbol{\omega}_{\mathrm{D}}, \\
& \boldsymbol{\omega}_{1}-\boldsymbol{\omega}_{2}+\boldsymbol{\omega}_{\mathrm{D}}, \\
& \boldsymbol{\omega}_{1}-\boldsymbol{\omega}_{2}-\boldsymbol{\omega}_{\mathrm{D}}
\end{aligned}
$$

Depending on the relative magnitudes of $\boldsymbol{\omega}_{\mathbf{2}}$ and $\boldsymbol{\omega}_{\mathbf{D}}$ with respect to $\boldsymbol{\omega}_{\mathbf{1}}$, we can get Stokes and anti-Stokes lines. If $\boldsymbol{\omega}_{2}>\boldsymbol{\omega}_{\mathbf{D}}$, then the following frequencies will correspond to anti-Stokes lines, i.e.

$$
\boldsymbol{\omega}_{1}+\boldsymbol{\omega}_{2}+\boldsymbol{\omega}_{\mathrm{D}} \text { and } \boldsymbol{\omega}_{1}+\boldsymbol{\omega}_{2}-\boldsymbol{\omega}_{\mathrm{D}}
$$

whereas the following will correspond to Stokes lines

$$
\boldsymbol{\omega}_{1}-\boldsymbol{\omega}_{2}+\boldsymbol{\omega}_{\mathrm{D}} \text { and } \boldsymbol{\omega}_{1}-\boldsymbol{\omega}_{2}-\boldsymbol{\omega}_{\mathrm{D}}
$$

Now $\boldsymbol{\omega}_{1}$ is the frequency of the incident radiation and this will be known since the frequency of the selected incident light radiation for the experiment will be known. Then $\boldsymbol{\omega}_{2}$ is the frequency of oscillation of the induced dipole and this will also be known for a given molecule. Now to calculate $\boldsymbol{\omega}_{\mathbf{D}}$, we have to first calculate the oscillating electric field $\left(\mathbf{E}_{\mathbf{L}}\right)$ of the oscillating dipole of the molecule, and then calculate the energy due to this oscillating electric field. If this energy is denoted by $\mathbf{U}$, then $\mathbf{U}=\hbar \boldsymbol{\omega}_{\mathrm{D}}$ will give the value of $\boldsymbol{\omega}_{\mathrm{D}}$.

Some of the important objectives of this research are as follows:

(i) Since the incident radiation creates oscillating dipole, and the oscillating dipole creates oscillating electric field, it must therefore affect the oscillating dipole. This in turn leads us to $\omega_{\mathrm{D}}$ that results in Stokes and anti-Stokes lines with new frequencies.

(ii) Electromagnetic field emitted or scattered by molecules located in close proximity can be used in areas such as chemical and material science art restorations, military, plasmonics nanoparticles, the existence of cancerous and healthy cells, infections and hereditary diseases [8-15].

(iii) It may motivate scientist to develop intense electric field lasers so that the value of $\boldsymbol{\omega}_{\mathrm{D}}$ can be increased such that the phenomena can be easily observed experimentally.

As usual there could be a larger or small gap between the proposed theory and the design of an experiment that can lead to the observation of the phenomena. For instance, Raman scattering was theoretically proposed in 1923, but discovered in 1928 [1,2]. The theory of simulated emission was proposed by Albert Einstein in 1917, but laser was discovered in 1960. Quite a few examples such, assuperconductivity, can be worth mentioning. 


\section{FORMULATION}

We have to calculate the oscillating electric field $\left(\mathbf{E}_{\mathbf{L}}\right)$ of a dipole (oscillating dipole) when the charge at its two ends is alternating with the angular frequency $\boldsymbol{\omega}(\boldsymbol{\omega}=\mathbf{2} \boldsymbol{\pi} \mathbf{f})$. Thus we have alternating charges ${ }^{+} \mathbf{q}$ and $^{-} \mathbf{q}$ such that,

$$
\mathrm{q}=\mathrm{Q} \cos \omega \mathrm{t},
$$

where Q - Is the maximum value of the charge on either sides.

Now to calculate the value of the oscillating electric field $\left(\mathbf{E}_{\mathbf{L}}\right)$ at the point of observation $\mathrm{P}$, we have to know the value of the electric field at point $P$ due to both charges, ${ }^{+} \mathbf{q}$ and $-\mathbf{q}$. Thus to know the value of $\mathrm{E}_{\mathrm{L}}$ at $\mathrm{P}$ due to the charges, we must consider that the apparent value of the charge is not $\mathbf{q}$ given as by Eqn. (8), but the value of q at some earlier moment. This is the moment at which a disturbance would have had to be emitted by the charge, and travelling at the speed of light $\mathbf{c}$, to reach at the point $\mathrm{P}$. The time of delay is $\frac{r_{1}}{c}$, and hence the apparent value of the charge will be

$$
q_{1}=Q \cos \omega\left(t-\frac{r_{1}}{c}\right),
$$

where $\mathrm{r}_{1}$ - distance between the center of the dipole and the point of observation $\mathrm{P}$.

Similarly, for the charge $\mathrm{q}_{2}$, we write

$$
q_{2}=-Q \cos \omega\left(t-\frac{r_{2}}{c}\right)
$$

It should be noted that the apparent charge is a function of its distance from the observer (point P), and this is clear from Eqn. (9) and Eqn. (10). Secondly, with the oscillating dipole, the amount of this time delay is different for the two charges since they are at different distances $\left(r_{1} \neq r_{2}\right)$ from $P\left(\right.$ only when $\Theta=90^{\circ}=\frac{\pi}{2}$, that $\left.r_{1}=r_{2}\right)$. Thus viewed in this way, the apparent total charge on the dipole is not zero $\left(\mathrm{q}_{1} \neq \mathrm{q}_{2}\right)$ but fluctuates between positive and negative values. The apparent charge $\mathrm{q}_{\mathrm{app}}$ can be written as,

$$
\begin{aligned}
q_{a p p}=q_{1} & +q_{2}=Q\left[\cos \omega\left(t-\frac{r_{1}}{c}\right)-\cos \omega\left(t-\frac{r_{2}}{c}\right)\right] \\
& =-2 Q \sin \omega\left(t-\frac{r}{c}\right) \sin \left(\frac{\omega l}{2 c} \cos \theta\right),
\end{aligned}
$$

where it is assumed that $r \gg l$, and

$$
r=\frac{1}{2}\left(r_{1}+r_{2}\right) \text { and } r_{1}-r_{2} \cong-l \cos \theta,
$$

where $l$ is the distance between the charges ${ }^{+} \mathrm{q}$ and ${ }^{-} \mathrm{q}$.

We should note that when $\boldsymbol{\omega}=0$ (static dipole), $\mathrm{q}_{\mathrm{app}}=0$, the field is localized and no oscillations. Now since $\boldsymbol{\omega}$ is finite and the apparent value of the total charge is not zero, the field has a longer range, and falls off less rapidly with the distance. Assuming that the length of the dipole is very short compared to the wavelength, $\lambda$, of the disturbance it sends out, we can write,

$$
\frac{l}{\lambda}=\frac{\omega l}{2 \pi c} \ll 1 \quad\left(\lambda=\frac{c}{f}=\frac{2 \pi c}{\omega}\right) .
$$

Using Eqn. (13) in Eqn. (11), we can write $\sin \theta \cong \theta$ when $\theta$ is very small, and hence Eqn. (11) can be written as,

$$
q_{\text {app }} \cong-\frac{\omega l}{c} Q \cos \theta \cdot \sin \omega\left(t-\frac{r}{c}\right) \text {. }
$$

Here $\mathrm{Q} l$ is the maximum value of the dipole moment $p_{0}$ of the dipole, such that we can write,

$$
p_{0}=Q l,
$$

and

$$
q_{\text {app }}=-\frac{\omega p_{0}}{c} \cos \theta \cdot \sin \omega\left(t-\frac{r}{c}\right) .
$$

We have now to evaluate the potential, $v$, which the dipole produces at the point $\mathrm{P}$. If $v_{1}$ is the potential at $\mathrm{P}$ due to the upper charge, and $v_{2}$ is the potential at $\mathrm{P}$ due to the lower charge, then,

$$
v=v_{1}+v_{2},
$$

where

$$
\begin{aligned}
& v_{1}=\frac{q_{1}}{4 \pi \varepsilon_{0} r_{1}}, \\
& v_{2}=\frac{q_{2}}{4 \pi \varepsilon_{0} r_{2}} .
\end{aligned}
$$


Combining Eqns. (9), (10), (17), (18) and (19), we can write,

$$
v=v_{1}+v_{2}=\frac{Q}{4 \pi \varepsilon_{0}}\left[\frac{\cos \omega\left(t-\frac{r_{1}}{c}\right)}{r_{1}}-\frac{\cos \omega\left(t-\frac{r_{2}}{c}\right)}{r_{2}}\right] .
$$

Assuming that the size of the dipole, $l$ is very small compared to $r_{1}$ and $r_{2}$ then $r_{1}$ and $r_{2}$ may be almost equal to each other. Using the approximations, we get,

$$
v=-\frac{Q l}{4 \pi \varepsilon_{0}} \frac{\partial}{\partial z}\left[\frac{\cos \omega\left(t-\frac{r}{c}\right)}{r}\right] .
$$

Eqn. (21) gives the basic formula for the potential due to the oscillating dipole. By putting $\boldsymbol{\omega}=0$, we get the potential for a stationary dipole. Eqn. (21) can be rewritten as,

$$
\begin{gathered}
v=-\frac{Q l}{4 \pi \varepsilon_{0}} \frac{\partial}{\partial r}\left[\frac{\cos \omega\left(t-\frac{r}{c}\right)}{r}\right] \frac{\partial r}{\partial z} . \\
=-\frac{Q l}{4 \pi \varepsilon_{0}} \cdot \cos \theta \cdot \frac{\partial}{\partial r}\left[\frac{\cos \omega\left(t-\frac{r}{c}\right)}{r}\right] \\
=\frac{Q l}{4 \pi \varepsilon_{0}} \cos \theta \cdot\left[\frac{\cos \omega\left(t-\frac{r}{c}\right)}{r^{2}}-\frac{\omega}{c} \frac{\sin \omega\left(t-\frac{r}{c}\right)}{r}\right] .
\end{gathered}
$$

Here in Eqn. (22), the first term refers to the static potential $(\boldsymbol{\omega}=0)$, and the second term gives the electrostatic potential that would be produced by the apparent charge $q_{\text {app }}$ given by Eqn. (16). In order to get the limiting form of $v$ for large distances, $r$. It is evident that the second term in Eqn. (22) becomes quite large compared to the first term (since the second term has $\mathrm{r}$ in the denominator, and the first term has $\mathrm{r}^{2}$ in the denominator). Thus the asymptotic value of $v$ can be written as,

$$
v \cong-\frac{Q l \omega}{4 \pi \varepsilon_{0} c} \cos \theta \cdot \frac{\sin \omega\left(t-\frac{r}{c}\right)}{r} .
$$

From Eqn. (23) we can calculate the electric field strength $\mathrm{E}$ in polar coordinates $r, \theta, \emptyset$. It can be shown that at large distance $r$, the components of $\mathrm{E}$ that are denoted by $\mathrm{E}_{\mathrm{r}}$ (in the direction of increasing $\mathrm{r}$ ), $E_{\theta}$, (in the direction of increasing $\theta$ ), and $E_{\varnothing}$ (in the direction of increasing $\emptyset$ ) have different values. In fact,

$$
E_{r} \cong 0 \text { and } E_{\varnothing}=0 \text {, }
$$

whereas,

$$
E_{\theta} \cong \frac{Q l \omega^{2}}{4 \pi \varepsilon_{0} c^{2}} \sin \theta \frac{\cos \omega\left(t-\frac{r}{c}\right)}{r} .
$$

Eqn. (25) shows that at large distances from the dipole the electric field $\mathrm{E}\left(\cong E_{\theta}\right)$ becomes entirely transverse, at whatever direction relative to the dipole it is measured, and transversality is a necessary condition for the plane electromagnetic radiation. (At large distances from the source, any wave become a plane wave).

It is important to understand that Raman Effect is a result of inelastic interaction between light and matter. This interaction can in turn, generate linear and nonlinear optical phenomena,depending on the strength of the applied electric field and the nature of the sample on which light falls. For instance, the electric field intensities must be higher than typically $10^{9} \mathrm{~V} / \mathrm{m}$ to make the contributions of the induced dipole moment large enough to create a nonlinear effect in the medium [16]. Such high electric field intensities can be obtained by using giant- pulse lasers. In fact, linear scattering can be obtained when the frequency of the incident light (stream of photons) $\boldsymbol{\omega}_{0}$ is far away from the molecular electronic absorption frequency $\boldsymbol{\omega}_{1}$ such that $\omega_{v} \ll \omega_{0} \ll \omega_{1}$, where $\omega_{v}$ is the vibrational frequency of the molecule. This is in line with the restriction of photon wavelength (energy) which lies in between the visible and near-visible regions and corresponds to vibrational and electronic molecular excitation energies. In this case, the photon transfers its energy $\left(\hbar \omega_{0}\right)$ to the whole molecule in order to displace the electron and produce an induced dipole moment. However, the electron remains bound since the large mass of the molecule does not allow such a transition. Hence, most of the incident light (photon) is transmitted without change of frequency and this type of scattering is called Rayleigh scattering, and is also known as elastic scattering.

It is necessary to understand that the origin of the Stokes and anti-Stokes scattering can be explained in terms of energy transfer between the incident light (photons) and the scattering system. When the molecule is initially excited to a level above the ground state, the scattered photon will gain energy and this scattering is termed as anti-Stokes scattering when the energy of the scattered radiation is $\hbar\left(\omega_{0}+\omega_{v}\right)$. However, if the molecule is initially at the lowest level (the ground state), the scattered photon will lose energy and is called Stokes scattering whose energy is $\hbar\left(\omega_{0}-\omega_{v}\right)$ [17].

The magnetic field associated with the radiation emitted by the oscillating dipole is, B, i.e. 


$$
B=\frac{Q l \omega^{2}}{4 \pi \varepsilon_{0} c^{3}} \sin \theta \cdot \frac{\cos \omega\left(t-\frac{r}{c}\right)}{r} .
$$

Now $E_{\theta}$ and $\mathrm{B}$ are at right angles to $\mathbf{r}$, and at right angles to each other. The power radiated by the oscillating dipole will begiven by the Pointing vector ' $\mathrm{S}$ ' [18] which is,

$$
S=\frac{1}{\mu_{0}}(E x B)
$$

where

$$
\mu_{0}=\frac{1}{\varepsilon_{0} c^{2}}
$$

The average total power radiated is the surface integral of S over a sphere of radius $r$, and hence we get [6],

$$
\begin{gathered}
S=\frac{\mu_{0} \omega^{4} p_{0}^{2}}{12 \pi c} \text { where } p_{0}=Q l \\
=\frac{\omega^{4} p_{0}^{2}}{12 \pi \varepsilon_{0} c^{3}}
\end{gathered}
$$

If $\omega_{D}$ is the angular frequency $\left(\omega_{D}=2 \pi f_{D}\right)$ associated with this field, then we can write,

Between Eqns. (30) and (31), we get,

$$
S=\hbar \omega_{D}
$$

$$
\omega_{D}=\frac{\omega^{4} p_{0}^{2}}{12 \pi \varepsilon_{0} c^{3} \hbar} .
$$

Another method of calculating the energy, U, associated with the electric field $E_{\theta}$ will be to calculate the work done by the electricfield $E_{\theta}$ in the displacement of the charge say Q, i.e.,

$$
\begin{gathered}
U=E_{\theta} \cdot q \cdot r \\
=\frac{Q q l \omega^{2} \sin \theta}{4 \pi \varepsilon_{0} c^{2}}\left[\cos \omega\left(t-\frac{r}{c}\right)\right]
\end{gathered}
$$

Now

$$
\cos x=1-\frac{x^{2}}{2 !}+\frac{x^{4}}{4 !}+
$$

and for small $x$, we can approximate,

and hence $\mathrm{U}$ becomes,

$$
\cos x=\left(1-\frac{x^{2}}{2 !}\right)
$$

$$
U=\frac{Q q l \omega^{2} \sin \theta}{4 \pi \varepsilon_{0} c^{2}}-\frac{Q q l \omega^{2} \sin \theta}{4 \pi \varepsilon_{0} c^{2}} \cdot \omega^{2}\left(t-\frac{r}{c}\right)^{2} .
$$

Under initial conditions at just $\mathrm{t}=0$, the second term will have $\mathrm{c}^{4}$ in the denominator, and this term will be very small compared to the first term that will have $\mathrm{c}^{2}$ in the denominator. Thus Eqn. (37) gives $U$ as,

$$
U=\frac{Q q l \omega^{2} \sin \theta}{4 \pi \varepsilon_{0} c^{2}}
$$

Generally, the observations are made perpendicular to the z-axis, $\theta=90^{\circ}$, $\sin \theta=1$, and hence,

$$
\begin{aligned}
& U=\frac{Q q l \omega^{2}}{4 \pi \varepsilon_{0} c^{2}} \\
& =\frac{q p_{0} \omega^{2}}{4 \pi \varepsilon_{0} c^{2}}\left(p_{0}=Q l\right)
\end{aligned}
$$

here $\mathrm{Q}=$ charge of one end of the electric dipole, $\mathrm{q}=$ electron charge.

Now if $\omega_{D}$ is the angular frequency associated with this energy, then,

$$
U=\hbar \omega_{D} \text { or } \omega_{D}=\frac{U}{\hbar}=\frac{p_{0} \omega^{2} q}{4 \pi \varepsilon_{0} c^{2} \hbar}
$$

Now energy S given by Eqn. (30) is the energy radiated by the oscillating dipole, whereas the energy U given by Eqn. (40) is the energy fed into the oscillating dipole that was responsible for the creation of the oscillating electric field. It is this energy that can contribute to the Raman-shifted-frequencies or Raman scattering. Hence $\omega_{D}$ given by Eqn. (41) will affect the Stokes and anti-Stokes frequencies or lines.

\section{RESULTS}

Equations (41) have been used to determine angular frequency $\boldsymbol{\omega}_{\mathrm{D}}$ for some compounds whose Electric dipole moments and their angular frequency of vibration of the molecule were obtained from literature [19].

We considered krypton laser of the following wavelength (in $\mathrm{nm}$ ):799.3, 752.5, 728.7, 676.4, 647.1, 632.8, 568.2, 530.9, $514.5,488.0,454.6$, and 416.0, as incident radiation. The results of each compound considered are given in their respective tables below: 


\section{Ammonia compound ( $\left.\mathrm{NH}_{3}\right)$}

Electric dipole moment $\left(\mathrm{p}_{\mathrm{o}}\right)=1.4718$ Debye

Angular frequency of vibration of the molecule $\left(\boldsymbol{\omega}_{2}\right)=6.2907 \times 10^{14} \mathrm{~s}^{-1}$.

Angular frequency due to the electric dipole created by the vibrating molecule $\left(\boldsymbol{\omega}_{\mathrm{D}}\right)=1.9405 \times 10^{14} \mathrm{~s}^{-1}$

\begin{tabular}{|c|c|c|c|c|}
\hline $\boldsymbol{\omega}_{1} \times 10^{14} \mathrm{~s}^{-1}$ & $\boldsymbol{\omega}_{1}+\boldsymbol{\omega}_{2}+\boldsymbol{\omega}_{\mathrm{D}}$ & $\boldsymbol{\omega}_{1}+\boldsymbol{\omega}_{2}-\boldsymbol{\omega}_{\mathrm{D}}$ & $\boldsymbol{\omega}_{1}-\boldsymbol{\omega}_{2}-\boldsymbol{\omega}_{\mathrm{D}}$ & $\boldsymbol{\omega}_{1}-\boldsymbol{\omega}_{2}+\boldsymbol{\omega}_{\mathrm{D}}$ \\
\hline 45.3173 & 53.5485 & 49.6675 & 37.0861 & 40.9671 \\
\hline 41.4694 & 49.7006 & 45.8196 & 33.2382 & 37.1192 \\
\hline 38.6311 & 46.8623 & 42.9813 & 30.3999 & 34.2809 \\
\hline 36.6414 & 44.8726 & 40.9916 & 28.4102 & 32.2912 \\
\hline 35.5095 & 43.7407 & 39.8597 & 27.2783 & 31.1593 \\
\hline 33.1785 & 41.4097 & 37.5287 & 24.9473 & 28.8283 \\
\hline 29.7914 & 38.0226 & 34.1416 & 21.5602 & 25.4412 \\
\hline 29.1331 & 37.3643 & 33.4833 & 20.9019 & 24.7829 \\
\hline 27.8711 & 36.1023 & 32.2213 & 19.6399 & 23.5209 \\
\hline 25.8707 & 34.1019 & 30.2209 & 17.6395 & 21.5205 \\
\hline 25.0525 & 33.2837 & 29.4027 & 16.8213 & 20.7023 \\
\hline 23.8564 & 32.0876 & 28.2066 & 15.6252 & 19.5062 \\
\hline
\end{tabular}

\section{Nitrous Oxide $\left(\mathrm{N}_{2} \mathrm{O}\right)$ compound}

Electric dipole moment $\left(\mathrm{p}_{\mathrm{o}}\right)=0.16083$ Debye

Angular frequency of vibration of the molecule $\left(\boldsymbol{\omega}_{2}\right)=4.1927 \times 10^{14} \mathrm{~s}^{-1}$.

Angular frequency due to the electric dipole created by the vibrating molecule $\left(\boldsymbol{\omega}_{\mathrm{D}}\right)=1.4217 \times 10^{13} \mathrm{~s}^{-1}$.

\begin{tabular}{|c|c|c|c|c|}
\hline $\boldsymbol{\omega}_{1} \times 10^{14} \mathrm{~s}^{-1}$ & $\boldsymbol{\omega}_{1}+\boldsymbol{\omega}_{2}+\boldsymbol{\omega}_{\mathrm{D}}$ & $\boldsymbol{\omega}_{1}+\boldsymbol{\omega}_{2}-\boldsymbol{\omega}_{\mathrm{D}}$ & $\boldsymbol{\omega}_{1}-\boldsymbol{\omega}_{2}-\boldsymbol{\omega}_{\mathrm{D}}$ & $\boldsymbol{\omega}_{1}-\boldsymbol{\omega}_{2}+\boldsymbol{\omega}_{\mathrm{D}}$ \\
\hline 45.3173 & 49.6522 & 49.3678 & 40.9824 & 41.2668 \\
\hline 41.4694 & 45.8043 & 45.5199 & 37.1345 & 37.4189 \\
\hline 38.6311 & 42.9660 & 42.6816 & 34.2962 & 34.5806 \\
\hline 36.6414 & 40.9763 & 40.6919 & 32.3065 & 32.5909 \\
\hline 35.5095 & 39.8444 & 39.5600 & 31.1746 & 31.4590 \\
\hline 33.1785 & 37.5134 & 37.2290 & 28.8436 & 29.1280 \\
\hline 29.7914 & 34.1263 & 33.8419 & 25.4565 & 25.7409 \\
\hline 29.1331 & 33.4680 & 33.1836 & 24.7982 & 25.0826 \\
\hline 27.8711 & 32.2060 & 31.9216 & 23.5362 & 23.8206 \\
\hline 25.8707 & 30.2056 & 29.9212 & 21.5358 & 21.8202 \\
\hline 25.0525 & 29.3874 & 29.3874 & 20.7176 & 21.0020 \\
\hline 23.8564 & 28.1919 & 27.9069 & 19.2515 & 19.8059 \\
\hline
\end{tabular}

\section{Water $\left(\mathrm{H}_{2} \mathrm{O}\right)$ compound}

Electric dipole moment $\left(\mathrm{p}_{\mathrm{o}}\right)=1.8546$ Debye

Angular frequency of vibration of the molecule $\left(\boldsymbol{\omega}_{2}\right)=6.8941 \times 10^{14} \mathrm{~s}^{-1}$.

Angular frequency due to the electric dipole created by the vibrating molecule $\left(\boldsymbol{\omega}_{\mathrm{D}}\right)=4.4327 \times 10^{14} \mathrm{~s}^{-1}$.

\begin{tabular}{|c|c|c|c|c|}
\hline $\boldsymbol{\omega}_{1} \times 10^{14} \mathrm{~s}^{-1}$ & $\boldsymbol{\omega}_{1}+\boldsymbol{\omega}_{2}+\boldsymbol{\omega}_{\mathrm{D}}$ & $\boldsymbol{\omega}_{1}+\boldsymbol{\omega}_{2}-\boldsymbol{\omega}_{\mathrm{D}}$ & $\boldsymbol{\omega}_{1}-\boldsymbol{\omega}_{2}-\boldsymbol{\omega}_{\mathrm{D}}$ & $\boldsymbol{\omega}_{1}-\boldsymbol{\omega}_{2}+\boldsymbol{\omega}_{\mathrm{D}}$ \\
\hline 45.3173 & 56.6441 & 47.7787 & 33.9905 & 42.8559 \\
\hline 41.4694 & 52.7962 & 43.9308 & 30.1426 & 39.0080 \\
\hline 38.6311 & 49.9579 & 41.0925 & 27.3043 & 36.1697 \\
\hline 36.6414 & 47.9682 & 39.1028 & 25.3146 & 34.1800 \\
\hline 35.5095 & 46.8363 & 37.9709 & 24.1827 & 33.0481 \\
\hline 33.1785 & 44.5053 & 35.6399 & 21.8517 & 30.7171 \\
\hline 29.7914 & 41.1182 & 32.2528 & 18.4646 & 27.3300 \\
\hline 29.1331 & 40.4599 & 31.5945 & 17.8063 & 26.6717 \\
\hline 27.8711 & 39.1979 & 30.3325 & 16.5443 & 25.4097 \\
\hline 25.8707 & 37.1975 & 28.3321 & 14.5439 & 23.4093 \\
\hline 25.0525 & 36.3793 & 27.5139 & 13.7257 & 22.5911 \\
\hline 23.8564 & 35.1832 & 26.3178 & 12.5296 & 21.3950 \\
\hline
\end{tabular}


Sulphur dioxide $\left(\mathrm{SO}_{2}\right)$ compound

Electric dipole moment $\left(\mathrm{p}_{\mathrm{o}}\right)=1.63$ Debye

Angular frequency of vibration of the molecule $\left(\boldsymbol{\omega}_{2}\right)=2.1699 \times 10^{14} \mathrm{~s}^{-1}$.

Angular frequency due to the electric dipole created by the vibrating molecule $\left(\boldsymbol{\omega}_{\mathrm{D}}\right)=3.859 \times 10^{13} \mathrm{~s}^{-1}$

\begin{tabular}{|c|c|c|c|c|}
\hline $\boldsymbol{\omega}_{1} \times 10^{14} \mathrm{~S}^{-1}$ & $\boldsymbol{\omega}_{1}+\boldsymbol{\omega}_{2}+\boldsymbol{\omega}_{\mathrm{D}}$ & $\boldsymbol{\omega}_{1}+\boldsymbol{\omega}_{2}-\boldsymbol{\omega}_{\mathrm{D}}$ & $\boldsymbol{\omega}_{1}-\boldsymbol{\omega}_{2}-\boldsymbol{\omega}_{\mathrm{D}}$ & $\boldsymbol{\omega}_{1}-\boldsymbol{\omega}_{2}+\boldsymbol{\omega}_{\mathrm{D}}$ \\
\hline 45.3173 & 47.8731 & 47.1013 & 42.7615 & 43.5333 \\
\hline 41.4694 & 44.0252 & 43.2534 & 38.9136 & 39.6854 \\
\hline 38.6311 & 41.1869 & 40.4151 & 36.0753 & 36.8471 \\
\hline 36.6414 & 39.1972 & 38.4254 & 34.0856 & 34.8574 \\
\hline 35.5095 & 38.0675 & 37.2935 & 32.9537 & 33.7255 \\
\hline 33.1785 & 35.7343 & 34.9625 & 30.6227 & 31.3945 \\
\hline 29.7914 & 32.3472 & 31.5754 & 27.2356 & 28.0074 \\
\hline 29.1331 & 31.6889 & 30.9171 & 26.5773 & 27.3491 \\
\hline 27.8711 & 30.4269 & 29.6551 & 25.3153 & 26.0871 \\
\hline 25.8707 & 28.4265 & 27.6547 & 23.3149 & 24.0867 \\
\hline 25.0525 & 27.6083 & 26.8365 & 22.4967 & 23.2685 \\
\hline 23.8564 & 26.4122 & 25.6404 & 21.3006 & 22.0724 \\
\hline
\end{tabular}

\section{Ozone $\left(\mathrm{O}_{3}\right)$ compound}

Electric dipole moment $\left(\mathrm{p}_{\mathrm{o}}\right)=0.5337$ Debye

Angular frequency of vibration of the molecule $\left(\boldsymbol{\omega}_{2}\right)=2.0794 \times 10^{14} \mathrm{~s}^{-1}$.

Angular frequency due to the electric dipole created by the vibrating molecule $\left(\boldsymbol{\omega}_{\mathrm{D}}\right)=1.161 \times 10^{13} \mathrm{~s}^{-1}$.

\begin{tabular}{|c|c|c|c|c|}
\hline $\boldsymbol{\omega}_{1} \times 10^{14} \mathrm{~S}^{-1}$ & $\boldsymbol{\omega}_{1}+\boldsymbol{\omega}_{2}+\boldsymbol{\omega}_{\mathrm{D}}$ & $\boldsymbol{\omega}_{1}+\boldsymbol{\omega}_{2}-\boldsymbol{\omega}_{\mathrm{D}}$ & $\boldsymbol{\omega}_{1}-\boldsymbol{\omega}_{2}-\boldsymbol{\omega}_{\mathrm{D}}$ & $\boldsymbol{\omega}_{1}-\boldsymbol{\omega}_{2}+\boldsymbol{\omega}_{\mathrm{D}}$ \\
\hline 45.3173 & 47.5128 & 47.2806 & 43.1218 & 43.3540 \\
\hline 41.4694 & 43.6649 & 43.4327 & 39.2739 & 39.5061 \\
\hline 38.6311 & 40.8266 & 405944 & 36.4356 & 36.6678 \\
\hline 36.6414 & 38.8369 & 38.6047 & 34.4459 & 34.6781 \\
\hline 35.5095 & 37.7045 & 37.4725 & 33.3140 & 33.5462 \\
\hline 33.1785 & 35.3740 & 35.1415 & 30.9830 & 31.2152 \\
\hline 29.7914 & 31.9869 & 31.7547 & 27.5959 & 27.8281 \\
\hline 29.1331 & 31.3286 & 31.0961 & 26.9376 & 27.1698 \\
\hline 27.8711 & 30.0666 & 29.8344 & 25.6756 & 25.6756 \\
\hline 25.8707 & 28.0662 & 27.8340 & 23.6752 & 23.9074 \\
\hline 25.0525 & 27.2480 & 27.0158 & 22.8570 & 23.0892 \\
\hline 23.8564 & 26.0519 & 25.8197 & 21.6609 & 21.8931 \\
\hline
\end{tabular}

\section{Compounds with Carbon}

\section{Dichloromethane $\left(\mathrm{CH}_{4} \mathrm{CL}_{2}\right)$ compound}

Electric dipole moment $\left(\mathrm{p}_{\mathrm{o}}\right)=1.60$ Debye

Angular frequency of vibration of the molecule $\left(\boldsymbol{\omega}_{2}\right)=5.6537 \times 10^{14} \mathrm{~s}^{-1}$.

Angular frequency due to the electric dipole created by the vibrating molecule $\left(\boldsymbol{\omega}_{\mathrm{D}}\right)=2.5719 \times 10^{14} \mathrm{~s}^{-1}$.

\begin{tabular}{|c|c|c|c|c|}
\hline $\boldsymbol{\omega}_{1} \times 10^{14} \mathbf{s}^{-1}$ & $\boldsymbol{\omega}_{1}+\boldsymbol{\omega}_{2}+\boldsymbol{\omega}_{\mathrm{D}}$ & $\boldsymbol{\omega}_{1}+\boldsymbol{\omega}_{2}-\boldsymbol{\omega}_{\mathrm{D}}$ & $\boldsymbol{\omega}_{1}-\boldsymbol{\omega}_{2}-\boldsymbol{\omega}_{\mathrm{D}}$ & $\boldsymbol{\omega}_{1}-\boldsymbol{\omega}_{2}+\boldsymbol{\omega}_{\mathrm{D}}$ \\
\hline 45.3173 & 53.5429 & 48.3991 & 37.0917 & 42.2355 \\
\hline 41.4694 & 49.6950 & 44.5512 & 33.2438 & 38.3876 \\
\hline 38.6311 & 46.8567 & 41.8129 & 30.4055 & 35.5493 \\
\hline 36.6414 & 44.8670 & 39.7232 & 28.4158 & 33.5596 \\
\hline 35.5095 & 43.7351 & 38.5913 & 27.2839 & 32.4277 \\
\hline 33.1785 & 41.4041 & 36.2605 & 24.9529 & 30.0967 \\
\hline 29.7914 & 38.0170 & 32.8732 & 21.5658 & 26.7096 \\
\hline 29.1331 & 37.3587 & 32.2149 & 20.9075 & 26.0513 \\
\hline 27.8711 & 36.0967 & 30.9529 & 19.6455 & 24.7893 \\
\hline 25.8707 & 34.0963 & 28.9525 & 17.6451 & 22.7889 \\
\hline 25.0525 & 33.2781 & 28.1343 & 16.8269 & 21.9707 \\
\hline 23.8564 & 32.0820 & 26.9382 & 15.6308 & 20.7746 \\
\hline
\end{tabular}


Formic acid $\left(\mathrm{CH}_{2} \mathrm{O}_{2}\right)$ compound

Electric dipole moment $\left(\mathrm{p}_{\mathrm{o}}\right)=1.425$ Debye

Angular frequency of vibration of the molecule $\left(\boldsymbol{\omega}_{2}\right)=4.9618 \times 10^{14} \mathrm{~s}^{-1}$.

Angular frequency due to the electric dipole created by the vibrating molecule $\left(\boldsymbol{\omega}_{\mathrm{D}}\right)=1.7642 \times 10^{14} \mathrm{~s}^{-1}$.

\begin{tabular}{|c|c|c|c|c|}
\hline $\boldsymbol{\omega}_{1} \times 10^{14} \mathrm{~s}^{-1}$ & $\boldsymbol{\omega}_{1}+\boldsymbol{\omega}_{2}+\boldsymbol{\omega}_{\mathrm{D}}$ & $\boldsymbol{\omega}_{1}+\boldsymbol{\omega}_{2}-\boldsymbol{\omega}_{\mathrm{D}}$ & $\boldsymbol{\omega}_{1}-\boldsymbol{\omega}_{2}-\boldsymbol{\omega}_{\mathrm{D}}$ & $\boldsymbol{\omega}_{1}-\boldsymbol{\omega}_{2}+\boldsymbol{\omega}_{\mathrm{D}}$ \\
\hline 45.3173 & 52.0433 & 48.5149 & 38.5913 & 42.1197 \\
\hline 41.4694 & 48.1954 & 44.6670 & 34.7434 & 38.2718 \\
\hline 38.6311 & 45.3571 & 41.8287 & 31.9051 & 35.4335 \\
\hline 36.6414 & 43.3674 & 39.8390 & 29.9154 & 33.4438 \\
\hline 35.5095 & 42.2355 & 38.7071 & 28.7835 & 32.3119 \\
\hline 33.1785 & 39.9045 & 36.3761 & 26.4525 & 29.9809 \\
\hline 29.7914 & 36.5174 & 32.9890 & 23.0654 & 26.5938 \\
\hline 29.1331 & 35.8591 & 32.3307 & 22.4071 & 25.9355 \\
\hline 27.8711 & 35.5971 & 31.0687 & 21.1451 & 24.6735 \\
\hline 25.8707 & 32.5967 & 29.0683 & 19.1447 & 22.6731 \\
\hline 25.0525 & 31.7785 & 28.2501 & 18.3265 & 21.8549 \\
\hline 23.8564 & 30.5824 & 27.0540 & 17.1304 & 20.6588 \\
\hline
\end{tabular}

\section{Methanol $\left(\mathrm{CH}_{4} \mathrm{O}\right)$ compound}

Electric dipole moment $\left(\mathrm{p}_{\mathrm{o}}\right)=1.7$ Debye

Angular frequency of vibration of the molecule $\left(\boldsymbol{\omega}_{2}\right)=6.9394 \times 10^{14} \mathrm{~s}^{-1}$.

Angular frequency due to the electric dipole created by the vibrating molecule $\left(\boldsymbol{\omega}_{\mathrm{D}}\right)=4.1168 \times 10^{14} \mathrm{~s}^{-1}$.

\begin{tabular}{|c|c|c|c|c|}
\hline $\boldsymbol{\omega}_{1} \times 10^{14} \mathrm{~s}^{-1}$ & $\boldsymbol{\omega}_{1}+\boldsymbol{\omega}_{2}+\boldsymbol{\omega}_{\mathrm{D}}$ & $\boldsymbol{\omega}_{1}+\boldsymbol{\omega}_{2}-\boldsymbol{\omega}_{\mathrm{D}}$ & $\boldsymbol{\omega}_{1}-\boldsymbol{\omega}_{2}-\boldsymbol{\omega}_{\mathrm{D}}$ & $\boldsymbol{\omega}_{1}-\boldsymbol{\omega}_{2}+\boldsymbol{\omega}_{\mathrm{D}}$ \\
\hline 45.3173 & 56.3735 & 48.1399 & 34.2611 & 42.4947 \\
\hline 41.4694 & 52.5256 & 44.2920 & 30.4132 & 38.6468 \\
\hline 38.6311 & 49.6873 & 41.4537 & 27.5785 & 35.8085 \\
\hline 36.6414 & 37.6976 & 39.4640 & 25.5852 & 33.8188 \\
\hline 35.5095 & 46.5657 & 38.3321 & 24.4533 & 32.6869 \\
\hline 33.1785 & 44.2347 & 36.0011 & 22.1223 & 30.3559 \\
\hline 29.7914 & 40.8476 & 32.6140 & 18.7352 & 26.9688 \\
\hline 29.1331 & 40.1893 & 31.9557 & 18.0769 & 26.3105 \\
\hline 27.8711 & 38.9273 & 30.6937 & 16.8149 & 25.0485 \\
\hline 25.8707 & 36.9269 & 28.6933 & 14.8145 & 23.0481 \\
\hline 25.0525 & 36.1087 & 27.8751 & 13.9963 & 22.2299 \\
\hline 23.8564 & 34.9126 & 26.6790 & 12.8004 & 21.0338 \\
\hline
\end{tabular}

\section{Benzene $\left(\mathrm{C}_{6} \mathrm{H}_{6}\right)$ compound}

Electric dipole moment $\left(\mathrm{p}_{\mathrm{o}}\right)=0.4236$ Debye

Angular frequency of vibration of the molecule $\left(\boldsymbol{\omega}_{2}\right)=4.3228 \times 10^{14} \mathrm{~s}^{-1}$.

Angular frequency due to the electric dipole created by the vibrating molecule $\left(\boldsymbol{\omega}_{\mathrm{D}}\right)=3.9806 \times 10^{13} \mathrm{~s}^{-1}$

\begin{tabular}{|c|c|c|c|c|}
\hline $\boldsymbol{\omega}_{1} \times 10^{14} \mathrm{~s}^{-1}$ & $\boldsymbol{\omega}_{1}+\boldsymbol{\omega}_{2}+\boldsymbol{\omega}_{\mathrm{D}}$ & $\boldsymbol{\omega}_{1}+\boldsymbol{\omega}_{2}-\boldsymbol{\omega}_{\mathrm{D}}$ & $\boldsymbol{\omega}_{1}-\boldsymbol{\omega}_{2}-\boldsymbol{\omega}_{\mathrm{D}}$ & $\boldsymbol{\omega}_{1}-\boldsymbol{\omega}_{2}+\boldsymbol{\omega}_{\mathrm{D}}$ \\
\hline 45.3173 & 50.0382 & 49.2420 & 40.5964 & 41.3926 \\
\hline 41.4694 & 46.1903 & 45.3941 & 36.7485 & 37.5447 \\
\hline 38.6311 & 43.3520 & 42.5558 & 33.9102 & 34.7064 \\
\hline 36.6414 & 41.3623 & 40.5661 & 31.9205 & 32.7167 \\
\hline 35.5095 & 40.2304 & 39.4342 & 30.7886 & 31.5848 \\
\hline 33.1785 & 37.8994 & 37.1032 & 28.4576 & 29.2538 \\
\hline 29.7914 & 34.5123 & 33.7161 & 25.0705 & 25.8667 \\
\hline 29.1331 & 33.8540 & 33.0578 & 24.4122 & 25.2084 \\
\hline 27.8711 & 32.5920 & 31.7958 & 23.1502 & 23.9464 \\
\hline 25.8707 & 30.5916 & 29.7954 & 21.1498 & 21.9460 \\
\hline 25.0525 & 29.7734 & 28.9772 & 20.3316 & 21.1278 \\
\hline 23.8564 & 28.5773 & 27.7811 & 19.1355 & 19.9317 \\
\hline
\end{tabular}




\section{Propane $\left(\mathrm{C}_{3} \mathrm{H}_{8}\right)$ compound}

Electric dipole moment $\left(\mathrm{p}_{\mathrm{o}}\right)=0.084$ Debye

Angular frequency of vibration of the molecule $\left(\boldsymbol{\omega}_{2}\right)=5.6065 \times 10^{14} \mathrm{~s}^{-1}$.

Angular frequency due to the electric dipole created by the vibrating molecule $\left(\boldsymbol{\omega}_{\mathrm{D}}\right)=1.3278 \times 10^{13} \mathrm{~s}^{-1}$.

\begin{tabular}{|c|c|c|c|c|}
\hline $\boldsymbol{\omega}_{1} \times 10^{14} \mathrm{~s}^{-1}$ & $\boldsymbol{\omega}_{1}+\boldsymbol{\omega}_{2}+\boldsymbol{\omega}_{\mathrm{D}}$ & $\boldsymbol{\omega}_{1}+\boldsymbol{\omega}_{2}-\boldsymbol{\omega}_{\mathrm{D}}$ & $\boldsymbol{\omega}_{1}-\boldsymbol{\omega}_{2}-\boldsymbol{\omega}_{\mathrm{D}}$ & $\boldsymbol{\omega}_{1}-\boldsymbol{\omega}_{2}+\boldsymbol{\omega}_{\mathrm{D}}$ \\
\hline 45.3173 & 51.0566 & 50.7910 & 39.5780 & 39.8436 \\
\hline 41.4694 & 47.2087 & 46.9431 & 35.7301 & 35.9957 \\
\hline 38.6311 & 44.3704 & 44.1048 & 32.8918 & 33.1574 \\
\hline 36.6414 & 42.3807 & 42.1151 & 30.9021 & 31.1677 \\
\hline 35.5095 & 41.2488 & 40.9832 & 29.7702 & 30.0358 \\
\hline 33.1785 & 39.9178 & 38.6522 & 27.4392 & 27.7048 \\
\hline 29.7914 & 35.5307 & 35.2651 & 24.0521 & 24.3177 \\
\hline 29.1331 & 34.8724 & 34.6068 & 23.3938 & 23.6594 \\
\hline 27.8711 & 33.6104 & 33.3448 & 22.1318 & 22.3974 \\
\hline 25.8707 & 31.6100 & 31.3444 & 20.1314 & 20.3970 \\
\hline 25.0525 & 30.7918 & 30.5262 & 19.3132 & 19.5788 \\
\hline 23.8564 & 29.5957 & 29.3301 & 18.1171 & 18.3827 \\
\hline
\end{tabular}

Carbonyl chloride $\left(\mathrm{Cl}_{2} \mathrm{CO}\right)$ compound

Electric dipole moment $\left(\mathrm{p}_{\mathrm{o}}\right)=1.17$ Debye.

Angular frequency of vibration of the molecule $\left(\boldsymbol{\omega}_{2}\right)=1.0689 \times 10^{14} \mathrm{~s}^{-1}$.

Angular frequency due to the electric dipole created by the vibrating molecule $\left(\boldsymbol{\omega}_{\mathrm{D}}\right)=6.72 \times 10^{12} \mathrm{~s}^{-1}$.

\begin{tabular}{|c|c|c|c|c|}
\hline $\boldsymbol{\omega}_{1} \times 10^{14} \mathrm{~S}^{-1}$ & $\boldsymbol{\omega}_{1}+\boldsymbol{\omega}_{2}+\boldsymbol{\omega}_{\mathrm{D}}$ & $\boldsymbol{\omega}_{1}+\boldsymbol{\omega}_{2}-\boldsymbol{\omega}_{\mathrm{D}}$ & $\boldsymbol{\omega}_{1}-\boldsymbol{\omega}_{2}-\boldsymbol{\omega}_{\mathrm{D}}$ & $\boldsymbol{\omega}_{1}-\boldsymbol{\omega}_{2}+\boldsymbol{\omega}_{\mathrm{D}}$ \\
\hline 45.3173 & 46.4534 & 46.3190 & 44.1812 & 44.3156 \\
\hline 41.4694 & 42.6055 & 42.4711 & 40.3333 & 40.4677 \\
\hline 38.6311 & 39.7672 & 39.6328 & 37.4950 & 37.6294 \\
\hline 36.6414 & 37.7775 & 37.6431 & 35.5053 & 35.6397 \\
\hline 35.5095 & 36.6456 & 36.5112 & 34.3734 & 34.5078 \\
\hline 33.1785 & 34.3146 & 34.1802 & 32.0424 & 32.1768 \\
\hline 29.7914 & 30.9275 & 30.7931 & 28.6553 & 28.7897 \\
\hline 29.1331 & 30.2692 & 30.1348 & 27.9970 & 28.1314 \\
\hline 27.8711 & 29.0072 & 28.8728 & 26.7350 & 26.8694 \\
\hline 25.8707 & 27.0068 & 26.8724 & 24.7346 & 24.8690 \\
\hline 25.0525 & 26.1886 & 26.0542 & 23.9164 & 24.0508 \\
\hline 23.8564 & 24.9925 & 24.8581 & 22.7203 & 22.8547 \\
\hline
\end{tabular}

\section{DISCUSSION AND SUMMARY}

There are a number of important reasons as to why the development of Raman spectroscopy was very slow. An important reason is that the Raman Effect is very weak [20]. Hardly one part in a million of the total intensity of the incident light is elastically scattered (Rayleigh scattering), whereas for Raman scattering this value is one part in $10^{8}$ of the incident light intensity [21]. This is also the most important reason that the discovery of Raman Effect was delayed. Even the discovery of laser was delayed up to 1960, but once a large number of lasers with powerful beams were discovered, new laser techniques stimulated the field of molecular spectroscopy and Raman spectroscopy.

Raman Effect arises when a photon is incident on a molecule, and it interacts with the dipole created by the electric field of the incident light radiation. In fact, an oscillating dipole is created. Now an oscillating dipole creates an oscillating electric field, and in this manuscript it is assumed that the oscillating electric field, created by the oscillating dipole can affect the frequency scattered due to the Raman Effect. The modification in the frequency of the Stokes and anti-Stokes lines due to this effect is calculated and is denoted as $\boldsymbol{\omega}_{\mathrm{D}}$. The values of $\boldsymbol{\omega}_{\mathrm{D}}$ for different molecules have been calculated. These values are different for different molecules and are smaller than $\boldsymbol{\omega}_{1}$ and $\boldsymbol{\omega}_{2}$ by a factor of roughly 10 . We emphatically believe that it should be possible to measure the value of $\boldsymbol{\omega}_{\mathrm{D}}$ by an appropriate experimental design and by using an intense electric field laser. One method could be that two laser beams are used. First a Q-switched laser beam (pulse of a beam) is projected on the molecule and then a continuous wave $(\mathrm{CW}$ ) laser beam be projected on the same molecules. This process of getting Stokes and anti-Stokes lines may help in getting a specific value for $\boldsymbol{\omega}_{\mathrm{D}}$ for different molecules. This process can be called double beam Raman scattering. It is not easy to surmise how soon the exact value of $\boldsymbol{\omega}_{\mathrm{D}}$ can be measured since the gap between theoretical prediction and experimental observation has beengenerally large. Moreover, an intense electric field laser can lead to larger $\boldsymbol{\omega}_{\mathrm{D}}$ values that can be measured. Intense electric field 
can affect $\boldsymbol{\omega}_{\mathrm{D}}$, but larger number of photons in the laser beam will affect the intensity of Raman lines. Typical electric field intensities of order of $10^{10} \mathrm{~V} / \mathrm{m}$ or more may be required to obtain values of $\boldsymbol{\omega}_{\mathrm{D}}$ that can be measured.

Raman spectroscopy provides a unique biochemical study capable of identifying and characterizing the structure of molecules, tissues, and cells. In identifying cervical cancer, it is established that it is a promising biochemical tool due to its ability to detect pre-malignancy and early malignancy stages [11-13, 22-25]. Raman lines differ between normal and malignant biopsy samples. In our case it is the value of $\boldsymbol{\omega}_{\mathrm{D}}$ that will differ between normal and malignant biopsy samples.

A greater body of experimental evidence may be needed in future to establish the validity of the theory developed in this manuscript. However, the fact remains that the type of Raman scattering proposed in this manuscript can be observed experimentally, and it can become a promising biomedical tool, especially by obtaining Raman lines after radiotherapy cycles and so on.

The concept in this manuscript is that the molecule may be excited not only by the incident laser radiation but also by the oscillating electric field created by the oscillating dipole. It is quite possible that our study can be used in the study of Four-Wave mixing microscopy of nanostructures [26], and Surface-Enhanced Raman Spectroscopy (SERS), and Coherent Raman Spectroscopy (CARS) [27-30,]. We are not competent to say how the experiments may be designed to observe these phenomena.

We must point out that we have not been able to find out any theoretical and or experimental observations on these lines in literature. From the above results, it shows that the theory developed predicts new phenomena of getting Stokes and anti-Stokes lines with modified wavelengths. It is proposed that such a phenomenon may be observed experimentally by using intense electric field laser.

\section{ORCID IDs}

(D) Khanna M. Kapil https://orcid.org/0000-0003-4311-9987, (DMurei K. Gilbert https://orcid.org/0000-0002-7250-3454

\section{REFERENCES}

[1] A. Smekal, Naturwiss, 11(43), 873-875(1923), https://doi.org/10.1007/BF01576902.

[2] C.V. Raman andK.S. Krishnan,Nature, 121, 501-502 (1928), https://doi.org/10.1038/121501c0.

[3] K.F. Kohlrauch, Der Smekal-Raman-Effect, (Springer, Berlin, 1931); Ergänzungsband 1931-1937, (Springer,1938).

[4] E. Garcia-Rico, R.A. Alvarez-Puebla, L. Guerrini, Chem. Soc. Rev. 47, 4909-4923 (2018), https://doi.org/10.1039/C7CS00809K.

[5] J.D. Jackson, Classical Electrodynamics, (Wiley, New York, 1975).

[6] L.D. Landau and E.M. Lifshitz, Electrodynamics of Continuous Media, (Pergamon, 1971).

[7] M. Born and E. Wolf, Principles of Optics, (Pergamon, 1970).

[8] A.N. Laurence, Journal of Raman spectroscopy, 41, (2017), https://doi.org/10.1002/jrs.5310.

[9] P. Rostron, S. Gaber and D. Gaber, IJETR, 6(1), 2454-4698 (2016), https://www.researchgate.net/profile/Paul_Rostron/ publication/309179824 Raman_Spectroscopy a review/links/580329fe08ae23fd1b673f34/Raman-Spectroscopy-a-review.pdf.

[10] B. Hruška, A.A. Osipov, L.M. Ösipova, M. Chromčíková, J. Macháček and M. Liškaac, Vibrational Spectroscopy, 105, 102970 (2019), https://doi.org/10.1016/j.vibspec.2019.102970.

[11] R.R. Jones, D.C. Hooper, Liwu Zhang, D. Wolverson and V.K. Valev, Nanoscale Res Lett. 14, 231 (2019), https://dx.doi.org/10.1186\%2Fs11671-019-3039-2

[12] R. Ravanshad, A.K. Zadeh, and A.M. Amani, Nano Reviews \& Experiments, 9(1), 1373551 (2018), https://doi.org/10.1080/20022727.2017.1373551.

[13] K.E. Sundling and A.C. Lowe, Advance Anat. Pathology, 26(1), 56-63 (2019), https://doi.org/10.1097/PAP.0000000000000217.

[14] S. Devpura, K.N. Barton, S.L. Brown, O. Palyvoda, S. Kalkanis, V.M. Naik, F. Siddiqui, R. Naik and I.J. Chetty, International Journal of Medical Physics Research and Practice, 41(5), 050901 (2014), https://doi.org/10.1118/1.4870981

[15] L. Guerrini and R.A. Alvarez-Puebla, Cancers, 11(6), 748 (2019), http://doi.org/10.3390/cancers11060748.

[16] Non-Linear Raman spectroscopy and its chemical applications, Proceedings of the NATO Advanced Study Institute held at Bad Windsheim, Germany, edited by W. Kiefer and D.A. Long (D. Reidel Publishing Company, London, 1982), pp. 643.

[17] A. Mohammed, H. Ågren and P. Norman, Chem. Phys. Lett. 468, 119-123 (2009), https://doi.org/10.1016/j.cplett.2008.11.063.

[18] D.J. Griffiths, Introduction to Electrodynamics, $3^{\text {rd }}$ edition,(Pearson Education, 2007).

[19] D.R. Lide, editor, CRC Handbook of Chemistry and Physics, Internet Version 2005, (CRC Press, Boca Raton, 2005), http://www.hbcpnetbase.com.

[20] H.J. Hibben, The Raman Effect and its Chemical Applications, (Reinhold Publishing Company, New York, 1939), https://doi.org/10.1002/ange.19400531511.

[21] D.A. Long, The Raman Effect: A Unified Treatment of the Theory of Raman Scattering by Molecules, (Willey, England, 2002), pp. 624.

[22] A. Mahadevan-Jansen, M.F. Mitchell, N. Ramanujamf, A. Malpica, S. Thomsen, U. Utzinger and R. Richards-Kortum, Photochemistry and Photobiology, 68(1), 123-132 (1998), https://doi.org/10.1111/j.1751-1097.1998.tb03262.x.

[23] A. Mahadevan-Jansen, M.F. Mitchell, N. Ramanujam, U. Utzinger and R. Richards-Kortum, Photochemistry and Photobiology 68(3), 427-431 (1998), https://doi.org/10.1111/j.1751-1097.1998.tb09703.x.

[24] P.R.T. Jess, D.D.W. Smith, M. Mazilu, K. Dholakia, A.C. Richesand and C.S. Herrington, International Journal of Cancer, 121(12), 2723-2728 (2007), https://doi.org/10.1002/ijc.23046.

[25] J.L. González-Solís, C. Martínez-Espinosa, L.A. Torres-González, A. Aguilar-Lemarroy, L.F. Jave-Suárez and P. PalomaresAnda, Lasers in Medical Science, 29(3), 979-985 (2014), https://doi.org/10.1007/s10103-013-1447-6.

[26] Yong Wang, Chia-Yu Lin, A. Nikolaenko, V. Raghunathan and E.O. Potma, Advances in Optics and Photonics, 3(1), 1-52 (2011), https://doi.org/10.1364/AOP.3.000001.

[27] Ji-Xin Cheng and Xiaoliang Sunney Xie, Coherent Raman scattering microscopy, (CRCPress, Taylor\&Francis group, 2013). 
[28] N. Buzgar, A.I. Apopei and A. Buzatu, (2009), Theory of Raman spectroscopy. Quantum and Classical Raman theory, http://www.rdrs.ro/blog/quantum-classical-raman-theory/.

[29] Theory of Raman spectroscopy, (2019), https://chem.libretexts.org/Bookshelves/Analytical_Chemistry/ Map\%3A_Principles_of_Instrumental_Analysis_(Skoog_et_al.)/18\%3A_Raman_Spectroscopy/18.1\%3A_Theory_of_Raman Spectroscopy.

[30] E.S. Winesett, C.H. Londergan and L.K. Charkoudian, Nat. Commun. 10(1), 2227 (2019), https://doi.org/10.1038/s41467-01910184-2.

\section{ВПЛИВ ОСЦИЛЮЮЧОГО ЕЛЕКТРИЧНОГО ПОЛЯ ЧЕРЕЗ ОСЦИЛЛЯЦЇ̈ ЕЛЕКТРИЧНОГО ДИПОЛЯ НА РАМАНІВСЬКІ ЛІНІЇ Ханна М. Капіл ${ }^{1}$, Мурей К. Гілберт ${ }^{2}$ \\ ${ }^{1}$ Кафедра фізики, Університет Ельдорет, Р.О. Вох 1125-30100, Eldoret, Кенія \\ ${ }^{2}$ Кафедра фізики, Університет Лайкіпія, Р.О. Вох 1100-20300, Ньяхуруру, Кенія}

Ефект Рамана полягає у вимірюванні інтенсивності та довжини хвиль непружно розсіяного випромінювання, яке падає на молекулу. Електричне поле випромінювання поляризує молекулу, на яку вона падає, і це призводить до створення коливань диполя. Поляризоване лазерне світло, що падає, непружно розсіюється молекулярним зразком. Розсіяне світло містить змінені довжини хвиль, які називаються Стоксівськими та анти-Стоксівськими довжинами хвиль. Електричний диполь, що коливається внаслідок падаючого випромінювання, створює навколо себе коливальне електричне поле. Оскільки коливальне електричне поле падаючого випромінювання створює коливальний електричний диполь, який створює навколо нього коливальне електричне поле, то вважається, що це коливальне електричне поле може впливати на частоту коливань або коливання електричного диполя, який його виробляє. Цей новий ефект змінить частоту (частоти) розсіяного випромінювання, що призведе до появи ліній Стокса та анти-Стокса зі зміненими частотами. Це теоретичне дослідження та його значення можна пояснити наступним чином. Наприклад, якщо є дві клітини або молекули поруч, у яких одна є здоровою клітиною, а інша - раковою, або два різних типів молекул що знаходяться поряд, цей тип розсіювання повинен бути в змозі розрізнити одну ситуацію від іншої, оскільки лінії Стокса і анти-Стокса від двох молекул не будуть ідентичними. Таким чином падаюче випромінювання кутової частоти $\boldsymbol{\omega} 1$ поляризує молекулу, на яку вона падає, і це призводить до створення коливального диполя частоти $\boldsymbol{\omega} 2$. Коливальний диполь створює коливальне електричне поле, яке може створити додаткову частоту коливального диполя, який його створив, і нехай це буде $\omega \mathrm{D}$. Тоді лінії Рамана можуть мати частоти $(\boldsymbol{\omega} 1+\boldsymbol{\omega} 2+\boldsymbol{\omega D})$, $(\boldsymbol{\omega} 1+\boldsymbol{\omega} 2-\boldsymbol{\omega D}),(\boldsymbol{\omega} 1-\boldsymbol{\omega} 2+\boldsymbol{\omega D})$ та $(\boldsymbol{\omega} 1-\boldsymbol{\omega} 2-\boldsymbol{\omega D})$. Залежно від відносних величин $\boldsymbol{\omega} 2$ і $\boldsymbol{\omega} \mathrm{D}$, лінії Рамана будуть позначатися як лінії Стокса і анти-Стокса. Через закон збереження енергії $\omega$ D буде менше ніж $\boldsymbol{\omega} 2$, оскільки коливальний диполь не може створити поле частоти більше своєї власної частоти. Отже, частоти $(\boldsymbol{\omega} 1-\boldsymbol{\omega} 2+\boldsymbol{\omega D})$ i $(\boldsymbol{\omega} 1-\boldsymbol{\omega} 2-\boldsymbol{\omega D})$ відповідають лініям Стокса і частотам. $(\boldsymbol{\omega} 1+\boldsymbol{\omega} 2+\boldsymbol{\omega D})$ i $(\boldsymbol{\omega} 1+\boldsymbol{\omega} 2-\boldsymbol{\omega D})$ будуть відповідати лініям анти-Стокса. Розрахунки ліній Стокса та анти-Стокса були зроблені для деяких молекул: аміаку $\left(\mathrm{NH}_{3}\right)$, оксиду азоту $\left(\mathrm{N}_{2} \mathrm{O}\right)$, води $\left(\mathrm{H}_{2} \mathrm{O}\right)$, діоксиду сірки $\left(\mathrm{SO}_{2}\right),\left(\mathrm{O}_{3}\right)$. Розрахунки також були проведені для сполук, що містять вуглець, таких як дихлорметан $\left(\mathrm{CH}_{4} \mathrm{Cl}_{2}\right)$, мурашиної кислоти $\left(\mathrm{CH}_{2} \mathrm{O}_{2}\right)$, метанолу $\left(\mathrm{CH}_{4} \mathrm{O}\right)$, бензолу $\left(\mathrm{C}_{6} \mathrm{H}_{6}\right)$, пропану $\left(\mathrm{C}_{3} \mathrm{H}_{8}\right)$ та карбонілхлориду $\left(\mathrm{Cl}_{2} \mathrm{CO}\right)$. Розроблена теорія передбачає нові явища для отримання ліній Стокса та анти-Стокса зі зміненою довжиною хвилі, які не спостерігалися експериментально на сьогоднішній день.

КЛЮЧОВІ СЛОВА: електричний диполь, лінії Рамана, лінії Стокса, анти-Стокса, коливальний електричний диполь

\section{ВЛИЯНИЕ ОСЦИЛЛИРУЮЩЕГО ЭЛЕКТРИЧЕСКОГО ПОЛЯ ЧЕРЕЗ ОСЦИЛЛЯЦИИ ЭЛЕКТРИЧЕСКОГО ДИПОЛЯ НА РАМАНОВСКИЕ ЛИНИИ Ханна М. Капил ${ }^{1}$, Мурей К. Гилберт ${ }^{2}$ \\ ${ }^{1}$ Кафедра физики, Университет Елдорет, Р.О. Вох 1125-30100, Елдорет, Кения \\ ${ }^{2}$ Кафедра физики, Университет Лайкипия, Р.О. Вох 1100-20300, Ньяхуруру, Кения}

Эффект Рамана состоит в измерении интенсивности и длины волн неупруго рассеянного излучения, которое падает на молекулу. Электрическое поле излучения поляризует молекулу, на которую она падает, и это приводит к созданию колебаний диполя. Поляризованный лазерный свет, падающий не упруго рассеивается молекулярным образцу. Рассеянный свет содержит изменены длины волн, которые называются Стоксовскими и анти-Стоксовскими длинами волн. Электрический диполь, который колеблется вследствие падающего излучения, создает вокруг себя колебательное электрическое поле. Поскольку колебательное электрическое поле падающего излучения создает колебательный электрический диполь, который создает вокруг него колебательное электрическое поле, то считается, что это колебательное электрическое поле может влиять на частоту колебаний или колебания электрического диполя, который его производит. Этот новый эффект изменит частоту (частоты) рассеянного излучения, что приведет к появлению линий Стокса и анти-Стокса с измененными частотами. Это теоретическое исследование и его значение можно объяснить следующим образом. Например, если есть две клетки или молекулы рядом, в которых одна является здоровой клеткой, а другая - раковой или два различных типов молекул, находящихся рядом, этот тип рассеяния должен быть в состоянии различить одну ситуацию от другой, поскольку линии Стокса и анти-Стокса от двух молекул не будут идентичными. Таким образом падающее излучение угловой частоты $\omega 1$ поляризует молекулу, на которую она падает, и это приводит к созданию колебательного диполя частоты 02 . Колебательный диполь создает колебательное электрическое поле, которое может создать дополнительную частоту колебательного диполя, который его создал, и пусть это будет $\omega \mathrm{D}$. Тогда линии Рамана могут иметь частоты $(\omega 1+\omega 2+\omega \mathrm{D}),(\omega 1+\omega 2-\omega \mathrm{D}),(\omega 1-\omega 2+\omega \mathrm{D})$ и $(\omega 1-\omega 2-\omega \mathrm{D})$. В зависимости от относительных величин $\omega 2$ и $\omega \mathrm{D}$, линии Рамана будут обозначаться как линии Стокса и антиСтокса. Через закон сохранения энергии $\omega \mathrm{D}$ будет меньше чем $\omega 2$, поскольку колебательный диполь не может создать поле частоты больше своей собственной частоты. Итак, частоты $(\omega 1-\omega 2+\omega \mathrm{D})$ и $(\omega 1-\omega 2-\omega \mathrm{D})$ соответствуют линиям Стокса и частотам. $(\omega 1+\omega 2+\omega \mathrm{D})$ и $(\omega 1+\omega 2-\omega \mathrm{D})$ будут соответствовать линиям анти-Стокса. Расчеты линий Стокса и анти-Стокса были сделаны для некоторых молекул: аммиака $(\mathrm{NH} 3)$, оксида азота $\left(\mathrm{N}_{2} \mathrm{O}\right)$, воды $\left(\mathrm{H}_{2} \mathrm{O}\right)$, диоксида серы $\left(\mathrm{SO}_{2}\right)$, озона $\left(\mathrm{O}_{3}\right)$. Расчеты также были проведены для соединений, содержащих углерод, таких как дихлорметан $\left(\mathrm{CH}_{4} \mathrm{Cl}_{2}\right)$, муравьиная кислота $\left(\mathrm{CH}_{2} \mathrm{O}_{2}\right)$, метанола соединение $\left(\mathrm{CH}_{4} \mathrm{O}\right)$, бензола $\left(\mathrm{C}_{6} \mathrm{H}_{6}\right)$, пропана $\left(\mathrm{C}_{3} \mathrm{H}_{8}\right)$ и карбонилхлорида $\left(\mathrm{Cl}_{2} \mathrm{CO}\right)$. Разработанная теория предполагает новые явления для получения линий Стокса и анти-Стокса с измененной длиной волны, что не наблюдались экспериментально на сегодняшний день.

КЛЮЧЕВЫЕ СЛОВА: электрический диполь, линии Рамана, линии Стокса, анти-Стокса, колебательный электрический диполь 